\title{
Role of Glucose and Insulin in the Dynamic Regulation of Glucagon Release by the Perfused Rat Pancreas
}

\author{
V. Leclercq-Meyer, J. Marchand and W. J. Malaisse \\ Laboratory of Experimental Medicine, Free University of Brussels, Brussels, Belgium
}

\begin{abstract}
Summary. The effect of glucose upon the release of glucagon and insulin from the perfused rat pancreas in vitro was studied by varying both the concentration of glucose (from 3.3 to $4.6,8.5$, or $11.1 \mathrm{mmol} / \mathrm{l}$ ) and the time of exposure to an elevated concentration of the sugar $(5,10$ or $23 \mathrm{~min})$. The results suggest that the amount of insulin released during the early period of stimulation could contribute to both the speed and extent of the inhibition in glucagon release. The rate of recovery from inhibition in the A cell, however, appeared to be independent of insulin and was related, in a dose-dependent
\end{abstract}

and time-dependent manner, only to the glucose stimulus. It is suggested that a direct effect of glucose upon the A cell is involved in the physiological regulation of glucagon secretion. An indirect effect of glucose, as mediated via insulin release, may contribute to the rapidity and magnitude of inhibition in A cell secretory activity.

Key words. Glucose, rat, glucagon release, insulin release, perfused rat pancreas.
The secretory responsiveness of the pancreatic A cell to glucose [1-5] is apparently altered in diabetes mellitus, since both the suppression of glucagon release by glucose and its stimulation in response to hypoglycaemia are impaired $[1,2,6]$. Several explanations have been proposed to account for such anomalies, including the lack of insulin in the peripheral circulation or within the islets $[2,7,8]$, a disruption of the normal topographical relationship between different cell types in the islets [7, 8], an intrinsic A cell defect at the level of either a hypothetical glucoreceptor [9] or the metabolism of glucose [10], or autonomic neuropathy [11]. It should be realized, however, that a delayed secretory response of the A cell to a decrease in extracellular glucose concentration may also occur in the absence of diabetes, e.g. when the extracellular glucose level in vitro is suddenly lowered after a prior exposure of normal pancreatic tissue to a high concentration of the sugar $[4,12-16]$ or in vivo towards the end of an oral or intravenous glucose tolerance test [17-20].

In the present study we have investigated whether the magnitude and duration of changes in the extracellular glucose concentration affect the rapidity and extent of the A cell secretory response. For this purpose the dynamics of glucagon release by the normal rat pancreas were examined in vitro in response to changes of variable amplitude and duration in the glucose concentration of the perfusate.

\section{Material and Methods}

\section{Animals and Technique}

The technique used to perfuse the rat pancreas has been described previously [12]. Briefly, fed female albino rats (Wistar or SpragueDawley strains; mean \pm SEM body weight: $273 \pm 5 \mathrm{~g} ; n=32$ ) were anaesthetized with sodium barbital ( $42 \mathrm{mg} / \mathrm{kg}$, IP). The entire pancreas was perfused through the coeliac and mesenteric arteries via a cannula inserted into the aorta, all adjacent organs, including the duodenum, being excluded.

\section{Methods}

The basal medium contained (in mmol/l) $\mathrm{NaCl}: 118.5, \mathrm{KCl}: 4.7$, $\mathrm{KH}_{2} \mathrm{PO}_{4}: 1.2, \mathrm{MgSO}_{4}: 1.2, \mathrm{CaCl}_{2}: 2, \mathrm{NaHCO}_{3}: 25$ and glucose:3.3. It was supplemented with dextran T70, $40 \mathrm{~g} / 1$ (Pharmacia, Uppsala, Sweden) and bovine albumin fraction $\mathrm{V}, 5 \mathrm{~g} / \mathrm{l}$, (Sigma Chemicals, $\mathrm{St}$. Louis, USA or Armour, Eastbourne, UK). It was equilibrated against a mixture of $\mathrm{O}_{2}$ and $\mathrm{CO}_{2}(95: 5)$, and entered the pancreas with a $\mathrm{pH}$ of 7.4 and a temperature of $37^{\circ} \mathrm{C}$. The flow rate averaged $1.98 \pm$ $0.01 \mathrm{ml} / \mathrm{min}(n=32)$ and the pressure amounted to $27.9 \pm 1.0 \mathrm{mmHg}$ $(3.7 \pm 0.1 \mathrm{kPa} ; n=32)$. The glucose pulses were administered through side-arm syringes working at a flow rate of $0.075 \mathrm{ml} / \mathrm{min}$ (Braun infusion pump, Melsungen, FRG). In a first series of experiments, glucose was administered in high concentration for either $23 \mathrm{~min}, 10 \mathrm{~min}$ or only $5 \mathrm{~min}$. In the latter case the concentration of glucose, which was intended to be $11.1 \mathrm{mmol} / 1$, only reached that of $8.5 \mathrm{mmol} / 1$ due to the dynamics of our perfusion system. In a second series of experiments, the concentration of glucose varied in a narrow range from 3.3 to $4.6 \mathrm{mmol} / 1$, the latter concentration being maintained for $23 \mathrm{~min}$. During the pre- and post-stimulatory periods, the osmolarity of the medium was adjusted to that obtained in the presence of glucose by the infusion of an equiosmolar amount of $\mathrm{NaCl}$. 


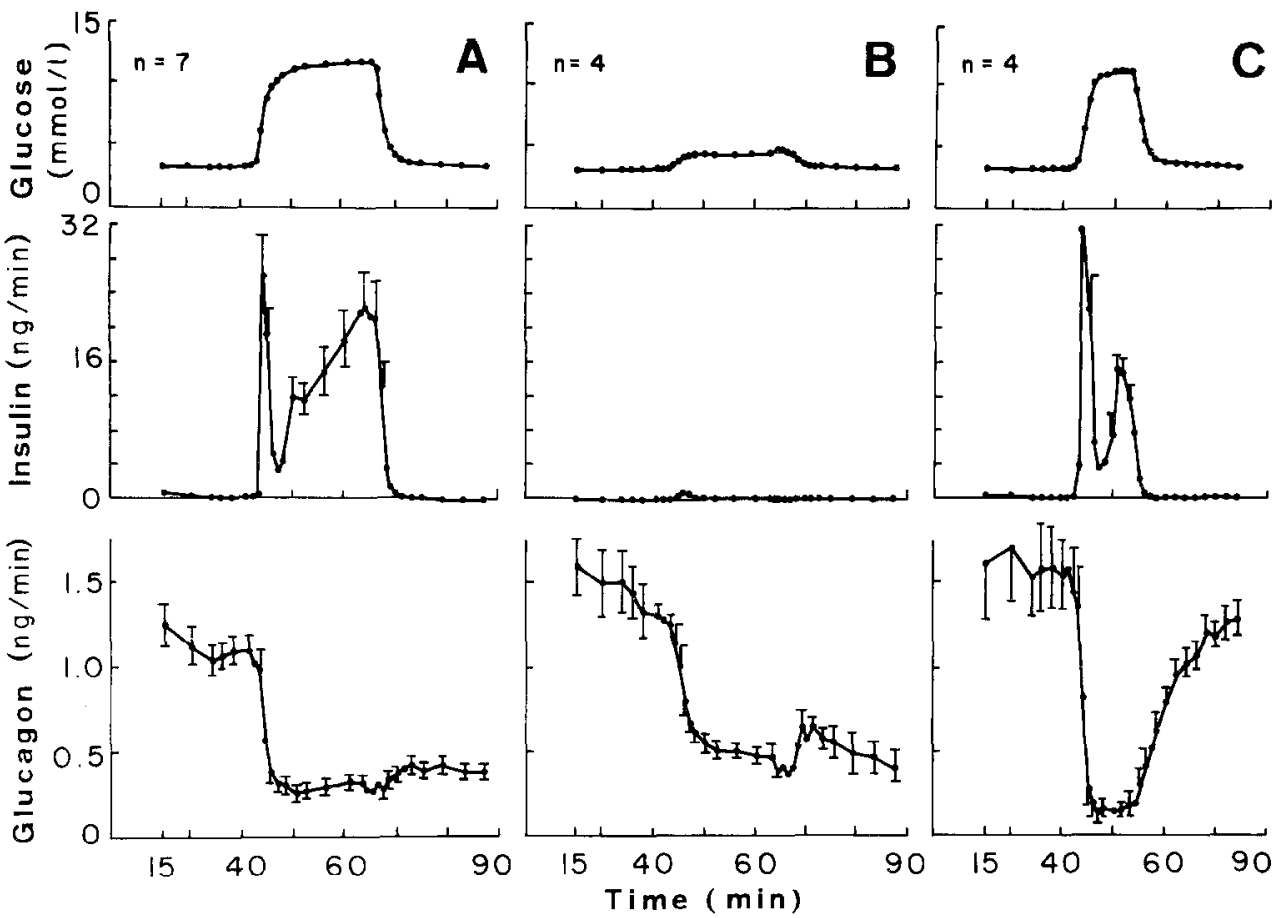

Fig. 1. Effects of glucose, administered at a high (up to $11.1 \mathrm{mmol} / 1$; $A$ and $C$ ) or a low concentration (up to $4.6 \mathrm{mmol} / \mathrm{l} ; B$ ) and for different lengths of time (23 min in $\mathrm{A}$ and $\mathrm{B}$, $10 \mathrm{~min}$ in $C$ ), upon the release of glucagon and insulin from the perfused rat pancreas. Results are shown as mean \pm SEM, together with the number of individual experiments $(\mathrm{n})$

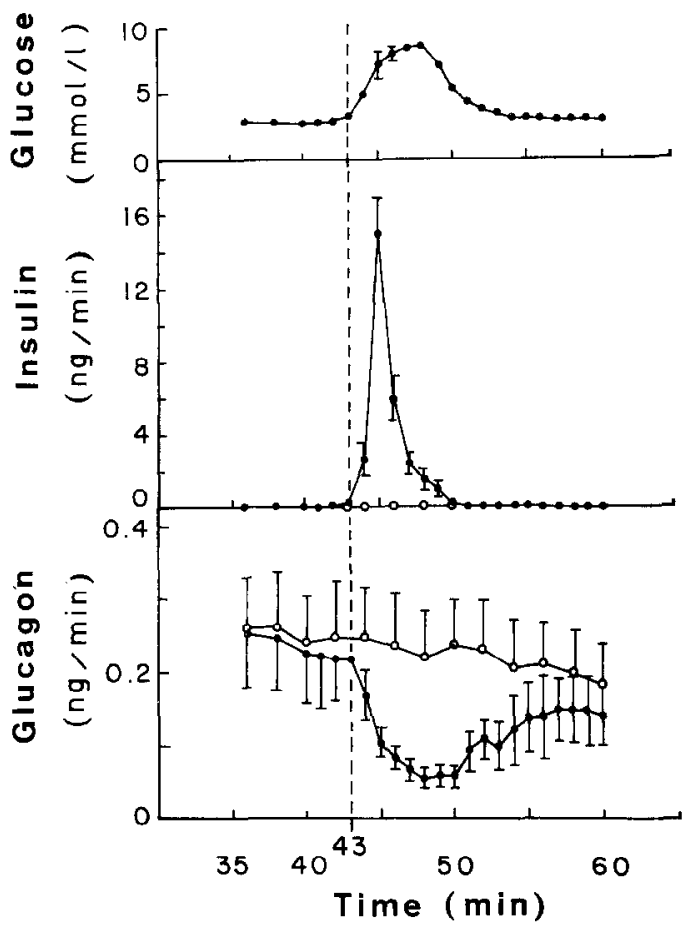

Fig. 2. Effects of a short ( $5 \mathrm{~min}$ ) pulse of glucose upon the release of glucagon and insulin from the perfused rat pancreas $(\bullet \longrightarrow, n=$ 9). Also shown are the results of control experiments performed in the presence of $3.3 \mathrm{mmol} / 1$ glucose throughout $\left(\mathrm{O}_{-}, n=7\right)$. Same presentation as in Fig. 1

Samples of the pancreatic effluent were collected, without recycling, at $1 \mathrm{~min}$ intervals in chilled glass tubes containing $2000 \mathrm{KIU}$ aprotinin (Trasylol, Bayer, Brussels, Belgium) and frozen at $-25^{\circ} \mathrm{C}$ until the time of assay. Glucagon and insulin levels were estimated using individual assays for these hormones [21]. In the glucagon assay, the ${ }^{125} \mathrm{I}$-glucagon tracers were obtained from several sources (Centre National de Transfusion Sanguine, Paris, France; New England Nuclear, Boston, USA; Novo, Bagsvaerd, Denmark). Porcine glucagon
(Novo) was used as the standard and a N- or C-terminal antibody from our laboratory was employed (AGS and 2601, respectively). Insulin was estimated using ${ }^{125} \mathrm{I}$-insulin (Institut National des Radioelements, Fleurus, Belgium or Radiochemical Centre, Amersham, UK), a guinea-pig anti-insulin serum (a gift from Dr. P. H. Wright, Indianapolis, USA) and rat insulin standard R170 (a gift from Dr. J.Schlichtkrull, Novo). In the case of glucagon, it might be noted that the basal rates of glucagon release (i. e. those observed at $3.3 \mathrm{mmol} / 1$ glucose) were about five times greater in our earlier experiments (performed in 1979; Figs 1 and 3) than in the more recent perfusions (performed in 1980-1981; Fig. 2). The reasons for such a quantitative difference were not found. Glucose was assayed in the pancreatic effluent with a glucose-oxidase method (GOD.PAP, Boehringer, Mannheim, FGR) using an AA-I Technicon analyzer.

\section{Statistical Analysis}

The results are presented as mean $\pm S E M$ together with the number of individual determinations ( $n$ ). Integrated glucagon and insulin release during each secretory phase and the amount of glucose which had perfused the pancreas were computed from the areas under the curves. The separation between the early and late phases of insulin release was judged from the lowest secretory rate recorded after the initial peak. In each individual experiment, the magnitude of the inhibitory effect of glucose upon glucagon output was calculated by comparing the last measurement during the control period (min 43) and the mean steady-state value reached during exposure to the higher concentration of glucose. The latter value was computed between minute 46 and either minute 50 ( 5 min stimulation), minute 54 ( $10 \mathrm{~min}$ stimulation) or minute 67 (23 min stimulation) inclusive when the glucose concentration was raised from 3.3 to $8.5 \mathrm{mmol} / 1$ or more, and between minutes 50 and 67 when the glucose concentration was raised for $23 \mathrm{~min}$ from 3.3 to only $4.6 \mathrm{mmol} / 1$. The time required to reach a steady-state glucagon output was estimated by graphical examination of each individual experiment. This method was validated by the fact that the concentration of glucagon in the first sample considered as representative of the new equilibrium stage was much lower than that found in the immediately preceding sample. Indeed, the paired difference in glucagon output between these two samples averaged $32.9 \pm$ $7.5 \%$ (geometric mean; $n=24 ; p<0.001$ ) of the corresponding mean stcady-state value recorded during exposure to the high concentration of glucose. Statistical analyses were conducted using the two-tailed non-paired t-test and the correlation coefficient $r$ [22]. 
Table 1. Effect of glucose upon glucagon and insulin release by the perfused rat pancreas.

\begin{tabular}{|c|c|c|c|c|c|c|c|}
\hline \multicolumn{3}{|l|}{ Glucose } & \multicolumn{2}{|c|}{ Glucagon release } & \multicolumn{3}{|c|}{ Insulin release } \\
\hline $11.8 \pm 0.3(7)$ & 23 & $0.60 \pm 0.02$ & $70.2 \pm 5.5$ & $3.6 \pm 0.4$ & $54.3 \pm 7.4$ & $327 \pm 62$ & $382 \pm 13$ \\
\hline $4.6 \pm 0.1$ & 23 & $0.26 \pm 0.01$ & $66.1 \pm 4.2$ & $8.5 \pm 0.5$ & $2.9 \pm 0.2$ & $2.9 \pm 0.7$ & $5.8 \pm 0.2$ \\
\hline
\end{tabular}

Results expressed as mean \pm SEM; number of individual experiments shown in parentheses

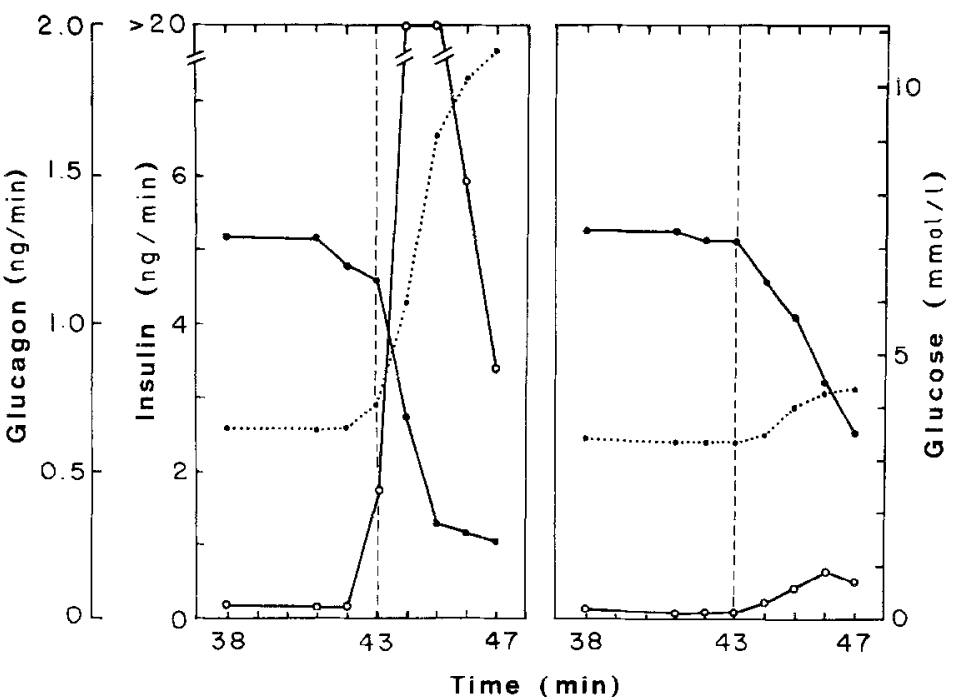

Fig. 3. Dynamics of the variations in the concentration of glucose $(\bullet . . . \cdots)$, glucagon $(-\infty)$ and insulin $(0-0)$ in the pancreatic effluent during the early minutes of the administration of glucose. Mean values refer to 11 (left panel) and 4 (right panel) individual experiments respectively

\section{Results}

\section{Time- and Dose-Dependent Inhibition of Glucagon Release}

The rise in the concentration of glucose resulted in an inhibition of glucagon release in all experiments (Figs. 1 and 2). Such an inhibition was least marked when the output of insulin during the early minutes of the infusion of glucose was lowest and most marked when the output of insulin during the early period was highest (Table 1). There was a positive correlation between the percentage inhibition of glucagon release and either the peak insulin concentration or the amount of insulin released during the early period of stimulation (Table 2 ). No correlation was found with other variables such as the amount of insulin released during the late phase, the total amount of glucose administered and the maximal levels of glucose reached during the experiments.

A significant fall in glucagon output was always observed at minute 44 either at the time when the concentration of glucose and insulin in the effluent were first increased or $1 \mathrm{~min}$ later (Fig. 3). The inhibition of glucagon release never preceded the stimulation of insulin release.

It clearly took less time to achieve a new steady-state level of glucagon secretion when the concentration of glucose was increased to $\geqslant 8.3 \mathrm{mmol} / 1$ than in response to a more modest increase in glucose concentration
(Table $1, p<0.001)$. There were significant correlations between the rapidity of the inhibition of glucagon secretion and both the amount of insulin released during the early period of stimulation and the maximal levels of glucose reached during the perfusions (Table 2).

\section{Time- and Dose-Dependent Reversal} of the Glucose-Induced Inhibition of Glucagon Release

The reversal from the glucose-induced inhibition of glucagon release appeared to be more a time-dependent than a dose-related phenomenon. Thus, when glucose was administered for $23 \mathrm{~min}$, whether at a high or a low concentration, the glucagon secretory rates recorded 15 min after restoration of a low glucose concentration (minute 80 at the end of the perfusion) amounted to only $40.6 \pm 8.8 \%$ and $47.6 \pm 6.0 \%$ respectively of the secretory rates which had been recorded immediately before the onset of inhibition of glucagon secretion (minute 43). On the other hand, when glucose was administered for shorter times (such as 10 or $5 \mathrm{~min}$ ) these late secretory rates amounted to $86.5 \pm 7.5 \%$ and $74.0 \pm 6.9 \%$, respectively. These late secretory rates of glucagon release were comparable to those seen towards the end of the perfusion in control experiments performed throughout in the presence of a fixed $3.3 \mathrm{mmol} / 1$ glucose concentration (Fig. 2). There was a significant inverse correlation between the rate of reversal from the glucose-induced inhibition of glucagon release and the time of exposure 
Table 2. The correlation between selected variables in individual experiments

\begin{tabular}{|c|c|c|c|c|}
\hline Part & Variables & $r$ & $t$ & $p$ \\
\hline \multirow[t]{7}{*}{1} & \multicolumn{4}{|l|}{ Inhibition of glucagon release (\%) } \\
\hline & $\begin{array}{l}\text { Versus early phase of insulin } \\
\text { release }\end{array}$ & 0.560 & 3.167 & $<0.01$ \\
\hline & $\begin{array}{l}\text { Versus early peak in insulin re- } \\
\text { lease }\end{array}$ & 0.602 & 3.538 & $<0.01$ \\
\hline & $\begin{array}{l}\text { Versus late phase of insulin re- } \\
\text { lease }\end{array}$ & 0.007 & 0.031 & NS \\
\hline & $\begin{array}{l}\text { Versus early + late phases of } \\
\text { insulin release }\end{array}$ & 0.094 & 0.444 & NS \\
\hline & $\begin{array}{l}\text { Versus total amount of glu- } \\
\text { cose administered }\end{array}$ & 0.101 & 0.466 & NS \\
\hline & Versus maximal glucose level & 0.353 & 1.730 & NS \\
\hline \multirow[t]{4}{*}{2} & \multicolumn{4}{|c|}{ Rapidity of the inhibition of glucagon release } \\
\hline & $\begin{array}{l}\text { Versus early phase of insulin } \\
\text { release }\end{array}$ & -0.425 & 2.200 & $<0.05$ \\
\hline & $\begin{array}{l}\text { Versus early peak in insulin re- } \\
\text { lease }\end{array}$ & -0.411 & 2.116 & $<0.05$ \\
\hline & Versus maximal glucose level & -0.687 & 4.326 & $<0.001$ \\
\hline \multirow[t]{5}{*}{3} & \multicolumn{4}{|c|}{ Percent reversal of the inhibition of glucagon release } \\
\hline & $\begin{array}{l}\text { Versus early }+ \text { late phases of } \\
\text { insulin release }\end{array}$ & -0.177 & 0.806 & NS \\
\hline & $\begin{array}{l}\text { Versus total amount of glu- } \\
\text { cose administered }\end{array}$ & -0.472 & 2.450 & $<0.05$ \\
\hline & Versus maximal glucose level & -0.182 & 0.345 & NS \\
\hline & $\begin{array}{l}\text { Versus time of exposure to } \\
\text { high glucose }\end{array}$ & -0.615 & 3.658 & $<0.01$ \\
\hline
\end{tabular}

Twenty-four experiments were performed in all cases

to the glucose stimulus (Table 2). A somewhat lower correlation was found between the rate of reversal and the total amount of glucose which had perfused the pancreas (Table 2). The lesser significance of the latter relationship was corroborated by the observation that an extensive reversal either occurred (Fig. 1C) or failed to do so (Fig. 1 B) although the total amount of glucose infused through the pancreas in either 10 or 23 min was the same $(0.26 \mathrm{mmol})$ in these two sets of experiments.

\section{Discussion}

The results of the present experiments confirm that the inhibition of glucagon release by glucose may fail to be rapidly reversed in a normal, non-diabetic, experimental preparation. Thus, a delayed recovery from inhibition in the A cell is not restricted to pathological conditions.

The role of insulin in mediating the response of the pancreatic A cell to changes in the environmental glucose concentration has remained a matter of debate over many years. On the one hand, it has been postulated that the A cells were devoid of intrinsic glucosesensing capacity, and that the effects of glucose were mediated indirectly, through the glucose-induced changes in insulin secretion $[2,7,8]$. On the other, there is evidence that glucagon secretion might not depend solely on insulin $[1,6]$. The results of the present experiments are compatible with the view that both glucose and insulin could be involved in the regulation of glucagon release. The relative importance of these two regulatory factors may differ, however, in the suppression of glucagon release by glucose and stimulation of glucagon release in response to hypoglycaemia, respectively.

The relationships found, between both the extent and the rapidity of the inhibition of glucagon release and the amount of insulin released during the early period of exposure to glucose, are compatible with the view, but do not demonstrate, that insulin is involved in the inhibition of A cell secretory activity in response to an increase in glucose concentration. A causal relationship between changes in insulin and glucagon release respectively is also compatible with the observation that the inhibition of glucagon output did not precede the stimulation of insulin release. This is not always the case, glucagon release being reported to precede insulin release in response to arginine [23].

Alternatively, it could be postulated that glucose exerts a direct effect upon the secretory activity of the A cell. This view is supported by the finding that inhibition of glucagon release occurred even when insulin was released at a very low rate. When the concentration of glucose was increased to $4.6 \mathrm{mmol} / 1$ for $23 \mathrm{~min}$, the integrated output of insulin did not exceed $5.8 \mathrm{ng}$ (or $3.2 \mathrm{mU} / \mathrm{l}$ ). That glucose can inhibit glucagon release in the virtual absence of insulin has been documented previously by other investigators $(3,24-28]$.

The concept of a dual control of glucagon release by both glucose and insulin cannot be ruled out. In several studies performed in normal pancreatic tissue, no direct effect of exogenous insulin upon glucagon release could be observed [24, 28-31]. However, in the presence of glucose, exogenous insulin was found to decrease glucagon output in pancreatic tissue removed from streptozotocin-treated guinea pigs and rats [31-33].

Recent studies suggest that the transport of glucose [34] and 3-O-methyl-glucose [35] in non-B islet cells occur more slowly than in B cells. Hence, the transport of glucose could represent a rate-limiting factor for its metabolism in the A cell and insulin could conceivably affect glucagon release by facilitating glucose transport.

A prolonged inhibition of glucagon release was noted upon the arrest of glucose infusion in high concentration and for a prolonged period of time. This confirms previous work performed with the perfused rat pancreas $[4,12-14,16]$. The same phenomenon was observed when glucose was administered for the same length of time but in a much lower concentration. Only when glucose was administered for a shorter time (5-10 min) did the glucagon secretory rate return rapidly to levels close to those seen before the glucose infusion.

The more or less rapid reversibility of glucagon release was apparently independent of insulin release and related only to the environmental glucose concentration and, even more, to the length of exposure to the sugar.

Once again the relationship between the rate of recovery in glucagon output and the magnitude and duration of the previous glucose administration could conceivably depend on the amount of glucose accumulated 
in the A cell during this prior treatment. If so, a greater than twofold increase in the length of exposure to glucose (from 10 to $23 \mathrm{~min}$ ) would seem to cause a greater accumulation of glucose than an equal increase in the concentration of the sugar (from 4.6 to $11.1 \mathrm{mmol} / 1$ ). This is not an unrealistic postulate since the relationship between glucose concentration and glucose transport affects a hyperbolic pattern (tending to saturation at high glucose concentrations) in those tissues in which glucose transport is indeed rate-limiting, e.g. in muscle.

In conclusion, the present findings emphasize the view that glucose per se apparently plays a critical role in the control of glucagon release whereas the possible indirect effect of glucose, as mediated via insulin release, appears to play, at the most, a modest modulating effect on the magnitude and rapidity of the inhibitory action of the sugar.

Acknowledgements. This work was supported in part by grants 3.4528.79 and 3.4519.80 from the Belgian Foundation for Scientific Medical Research.

\section{References}

1. Gerich JE, Charles MA, Grodsky GM (1976) Regulation of pancreatic insulin and glucagon secretion. Ann Rev Physiol 38: 353-388

2. Unger RH, Dobbs RE, Orci L (1978) Insulin, glucagon and somatostatin secretion in the regulation of metabolism. Ann Rev Physiol 40: 307-343

3. Gerich JE, Charles MA, Grodsky GM (1974) Characterization of the effects of arginine and glucose on glucagon and insulin release from the perfused rat pancreas. J Clin Invest 54: 833-841

4. Pagliara AS, Stillings SN, Hover B, Martin D, Matschinsky FM (1974) Glucose modulation of amino-acid induced glucagon and insulin release from the isolated perfused rat pancreas. J Clin Invest $54: 819-832$

5. Weir GC, Knowlton SD, Martin DB (1974) Glucagon secretion from the perfused rat pancreas. Studies with glucose and catecholamines. J Clin Invest 54: 1403-1412

6. Reach G, Assan R (1979) Glucagon and diabetes mellitus. Diab Métab 5: 63-70

7. Unger RH, Raskin P, Srikant CB, Orci L (1977) Glucagon and the A cells. Rec Progr Horm Res 33: 477-517

8. Unger RH, Orci L (1981) Glucagon and the A-cell. New Engl J Med 304: 1575-1580

9. Gerich JE, Langlois M, Noacco C, Karam JH, Forsham PH (1973) Lack of glucagon response to hypoglycemia in diabetes: evidence for an intrinsic alpha cell defect. Science 182:171-173

10. Day JL, Anderson J (1973) Abnormalities of glucagon metabolism in diabetes mellitus. Clin Endocr 2: 211-247

11. Campbell LV, Kraegen EW, Lazarus L (1977) Defective blood glucose counter-regulation in diabetics is a selective form of autonomic neuropathy. Br Med J 2: 1527-1529

12. Leclercq-Meyer V, Marchand J, Leclercq R, Malaisse WJ (1976) Glucagon and insulin release by the in vitro perfused rat pancreas. Influence of the colloid composition of the perfusate. Diab Métab 2: $57-65$

13. Leclercq-Meyer V, Marchand J, Leclercq R, Malaisse WJ (1979) Interactions of $\alpha$-ketoisocaproate, glucose and arginine in the secretion of glucagon and insulin from the perfused rat pancreas. Diabetologia 17: 121-126

14. Weir GC, Clore ET, Zmachinski CJ, Bonner-Weir S (1981) Islet secretion in a new experimental model for non insulin-dependent diabetes. Diabetes 30: 590-595

15. Collier S, Mandel TE, Hoffman L, Caruso G (1981) Organ culture of fetal mouse pancreas. The effect of culture conditions on insulin and glucagon secretion. Diabetes 30:804-812

16. Frankel BJ, Gerich JE, Hagura R, Fanska RE, Gerritsen GC, Grodsky GM (1974) Abnormal secretion of insulin and glucagon by the in vitro perfused pancreas of the genetically diabetic hamster. J Clin Invest 53: 1637-1646

17. Heding LG (1971) Radioimmunological determination of pancreatic and gut glucagon in plasma. Diabetologia 7: 10-19

18. De Fronzo RA, Hendler R, Christensen N (1980) Stimulation of counterregulatory hormonal responses in diabetic man by a fall in glucose concentration. Diabetes 29: 125 -131

19. Yamamoto T, Raskin P, Aydin I, Unger RH (1979) Effects of insulin on the response of immunoreactive glucagon to an intravenous glucose load in human diabetes. Metabolism 28: 568-574

20. Blackard WJ, Nelson C, Andrews SS (1974) Portal and peripheral vein immunoreactive glucagon concentrations after arginine or glucose infusions. Diabetes 23: 199-202

21. Leclercq-Meyer V, Marchand J, Rebolledo O, Malaisse WJ, Leclereq R (1975) A combined radioimmunoassay for glucagon and insulin. Diabetologia 11: 419-425

22. Snedecor AW, Cochran WG (1967) Statistical methods, 6th edn. Iowa University Press, Ames

23. Pek S, Tai TY, Crowther R, Fajans SS (1976) Glucagon release precedes insulin release in response to common secretagogues. Diabetes 25: 764-770

24. Matschinsky FM, Pagliara AS, Hover BA, Pace CS, Ferrendelli JA, Williams A (1976) Hormone secretion and glucose metabolism in islets of Langerhans of the isolated perfused pancreas from normal and streptozotocin diabetic rats. J Biol Chem 251: 6053-6061

25. Pagliara AS, Stillings SN, Zawalich WS, Williams AD, Matschinsky FM (1977) Glucose and 3-O-methylglucose protection against alloxan poisoning of pancreatic alpha and beta cells. Diabetes 26: 973-979

26. Matschinsky FM, Rujanavech C, Pagliara AS, Norfleet WT (1980) Adaptations of $\alpha_{2}$ - and $\beta$-cells of rat and mouse pancreatic islets to starvation, to refeeding after starvation and to obesity. J Clin Invest $65: 207-218$

27. Hermansen K (1981) Pancreatic D-cell recognition of D-glucose. Studies with D-glucose, D-glyceraldehyde, dihydroxyacetone, Dmannoheptulose, D-fructose, D-galactose and D-ribose. Diabetes 30: $203-210$

28. Goto Y, Berelowitz M. Frohman LA (1981) Acute effects of alloxan- and streptozotocin-induced insulin deficiency on somatostatin and glucagon secretion. Diabetologia 20: 66-71

29. Pagliara AS, Stillings SN, Haymond MW, Hover BA, Matschinsky FM (1975) Insulin and glucose as modulators of the amino acid-induced glucagon release in the isolated pancreas of alloxan and streptozotocin diabetic rats. J Clin Invest 55:244-255

30. Hermansen K, Ørskov H, Christensen SE (1979) Streptozotocin diabetes: a glucoreceptor dysfunction affecting $\mathrm{D}$ cells as well as $B$ and A cells. Diabetologia 17: 385-389

31. Östenson C-G (1979) Regulation of glucagon release: effects of insulin on the pancreatic $\mathrm{A}_{2}$-cell of the guinea pig. Diabetologia $17: 325-330$

32. Östenson C-G, Andersson A, Brolin SE, Petersson B, Hellerström $C$ (1977) Effects of insulin on the glucagon release, glucose utilization and ATP content of the pancreatic A cells of the guinea pig. In: Foà PP, Bajaj JS, Foà NL (eds) Glucagon: its role in physiology and clinical medicine, Springer, New York, Heidelberg, Berlin, pp 243-254

33. Weir CG, Knowlton SD, Atkins RF, Mc Kennan KX, Martin DB (1976) Glucagon secretion from the perfused pancreas of streptozotocin-treated rats. Diabetes 25: 275-282

34. Idahl L-A (1981) Glucose content in the A-cell islets of pigeon pancreas. Diabetologia 21: 284-285 (Abstract)

35. Malaisse WJ, Gorus FK, Pipeleers DG (1982) Alloxan uptake by pancreatic B and non-B islet cells. Biol Cell 45:282 (Abstract)

Received: 8 June 1982

and in revised form: 19 October 1982

Dr. V. Leclercq-Meyer

Laboratory of Experimental Medicine

Université Libre de Bruxelles

115, Boulevard de Waterloo

B-1000 Brussels, Belgium 